\title{
Analysis of swarm earthquakes around Mt. Agung Bali, Indonesia prior to November 2017 eruption using regional BMKG network
}

\author{
Mohamad Taufik Gunawan ${ }^{1 *}$, Ridwan Kusnandar ${ }^{1}$, Pepen Supendi ${ }^{1,2}$, Andri Dian Nugraha ${ }^{2,3}$, \\ Nanang T. Puspito ${ }^{2,3}$, Daryono', David P. Sahara ${ }^{2,3}$ and Zulfakriza ${ }^{2,3}$
}

\begin{abstract}
Mt. Agung, located in Karangasem-Bali, Indonesia, had a significant increase of swarm earthquakes from September 2017 until the recent eruption in November 2017. To analyze the seismic swarm and its correlation with the magmatic movement, we worked on the regional seismic data recorded by Agency for Meteorology, Climatology and Geophysics of Indonesia (BMKG) between September 14 to October 20, 2017. P-and S-wave phases of the swarm events had been manually picked. In total, 804 events in the time period of September 14 to October 20, 2017 were successfully determined. To improve the location precision, the double-difference relocation method was performed. We identified most of the events as Volcano-Tectonic type A (VT-A) earthquakes and located between Mt. Batur and Mt. Agung. Those events form a cluster striking in NE-SW direction at a depth between 2 and $20 \mathrm{~km}$. Focal mechanism solutions for selected events below Mt. Agung show a thrust and strike-slip faulting regime. Interestingly, a trend of event propagation toward the summit of Mt. Agung was observed. The frequency of VT-A event occurrences is significantly increased at the later stage of the swarms. We concluded that the increased seismic activity in Mt. Agung was due to the migration of magma from the deep chamber to the shallow reservoir.
\end{abstract}

Keywords: Mt. Agung, Bali, Seismicity, BMKG regional seismic stations, Double-difference relocation, Focal mechanism

\section{Introduction}

Mt. Agung, located in Karangasem-Bali, is one of the 127 active volcanoes in Indonesia and the eruption type is explosive. Based on the record of the Center for Volcanology and Disaster Hazard Mitigation of Indonesia (CVGHM), Mt. Agung (3.142 $\mathrm{m}$ above the mean sea level) has erupted four times, i.e. in 1808, 1821, 1843, and 1963. The latest eruption in 1963 caused 1148 people to die, and 296 others were injured. Before the 1963 eruption (from February 18, 1963), an increase of earthquake activity was felt by a resident in Yeh Kori Village

\footnotetext{
*Correspondence: taufik.gunawan.bali@gmail.com

${ }^{1}$ Agency for Meteorology, Climatology, and Geophysics (BMKG), Jakarta

10610, Indonesia

Full list of author information is available at the end of the article
}

located $6 \mathrm{~km}$ southeast Mt. Agung, in the region of Tianyar-Tejakula, north coast of Bali (Zen and Hadikusumo 1964). In 1963, The first major explosion produced a widespread ash fall that dispersed west-northwestwards, with ash fall being reported as far away as Bandung and Jakarta in western Java, a distance of about $1000 \mathrm{~km}$ from the volcano (Self and Rampino 2012). The eruption occurred during the wet season in Bali, and the pyroclastic flow and tephra fall deposits rapidly generated hot and cold lahars by mixing with the torrential rainfalls that followed. Heavy rains on Agung began eroding the pyroclastic deposits immediately after the explosive phase, devastating the lowlands with lahars that reached all the way to the coast (Fig. 3). The eruption caused many casualties and destruction of villages, largely from the pyroclastic flows and ensuing lahars (Self and Rampino 2012). 
Considering the scale and impact of 1963 eruption, the Indonesian government began to intensively monitor the activity of the volcano to mitigate the negative impacts of the volcanic eruption (Kusumadinata 1964). In general, an increase of volcanic activity can be noticed by observing the physical and chemical changes, e.g. physical change of volcanic smog from the crater (as well as its chemical composition), an increase in temperature in the crater, volcano deformation, and an increase of microseismic activity recorded on seismographs (McGuire 1992).

In this study, an analysis of Mt. Agung swarm earthquakes 2 months prior to the November 2017 eruption was performed. The correlation between swarm earthquakes, tectonic and magmatic activity has been observed in many places, especially in Indonesian regions, e.g. Mt. Pandan (Santoso et al. 2018), Jailolo volcano (Nugraha et al. 2018a), Bekancan (Nugraha et al. 2018b), the southern part of Garut, West Java (Supendi et al. 2018), West Halmahera (Nugraha et al. 2017b) among many others. Albino et al. (2019) suggested that the dike intrusion between neighboring arc volcanoes was responsible for the Mt. Agung 2017 eruption. A dike intrusion might be the source of the seismic swarm recorded at Mt. Agung.
In September to October 2017, seismic activity around Mt. Agung reached hundreds of events, some of which were felt by the local population. The initial location of BMKG showed that these earthquakes are located at a depth less than $40 \mathrm{~km}$. The aim of this study is to analyze the characteristics of VT events of Mt. Agung and its correlation with magma migration. An advanced analysis of sources relocation and their mechanism is performed in this study to improve the accuracy of the initial locations published by BMKG.

\section{Data and methods}

In the framework of Indonesian Tsunami Early Warning System (InaTEWS) operated by the Agency for Meteorology, Climatology and Geophysics of Indonesia (BMKG), there are 10-broadband seismic stations covering Mt. Agung (Fig. 1) with a sampling frequency of $40-100 \mathrm{~Hz}$. The 3-component waveform data of those 10 stations were retrieved for the time period from September 14 to October 20, 2017. The selection of the time period was based on the occurrence of the seismic events observed at Mt. Agung.

On 22 September 2017, the status of Mt. Agung was increased to level IV (warning) due to an increase of Volcano-Tectonic (VT) earthquakes intensity in the

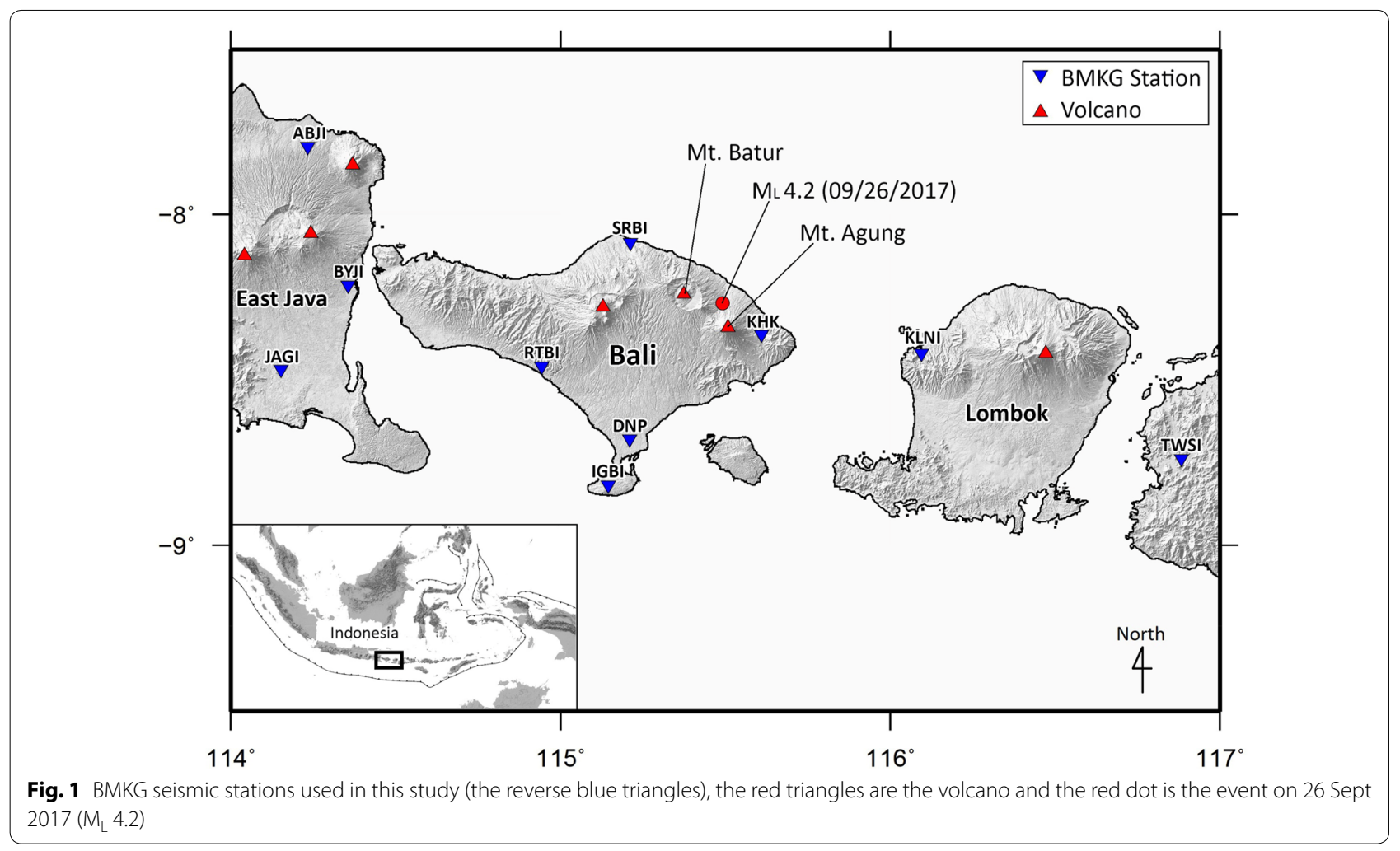


Mt. Agung area. CVGHM produced Volcano Observatory Notice for Aviation (VONA) reports based on analysis of data from the agency's monitoring networks as well as from direct observations. VONA's alert levels are color-coded to indicate the different types of notifications addressing specific informative needs. VONA's alert consists of levels I (normal), level II (advisory), level III (watch), and level IV (warning). Level IV implies an intensive increase of seismicity, monitoring of other obvious volcanic changes, and visual observations including the crater.

We have utilized the regional seismic network surrounding Mt. Agung to analyze the swarm earthquakes for the time period of September 14 to October 20, 2017. A double-difference technique was applied to improve the accuracy of the initial hypocenter location obtained in this study. A significant improvement of the location accuracy was demonstrated. A further source mechanism analysis of the earthquake swarm sequence was obtained through focal mechanism inversion. Furthermore, the seismic swarms obtained in this study could also be further processed to infer the internal structure of the volcano (Nugraha et al. 2017a; Widiyantoro et al. 2018).

VT earthquakes of a volcano are classified into VT type A (VT-A) and VT type B (VT-B) (McCausland et al. 2017; Iguchi et al. 2011). Stress accumulation is caused by magma intrusion to the surface, which might trigger slip on the nodal plane of the fault around the volcano. The mechanism and waveform signatures of this event are almost identical to that of a tectonic earthquake (McNutt 2002), therefore, we called it VT-A. These VT-A events have typical depths of more than $2 \mathrm{~km}$, high-frequency content (more than $5 \mathrm{~Hz}$ ), and clear time onsets of P-and $\mathrm{S}$-waves. On the other hand, VT-B earthquakes typically occurred at a shallower depth (1-2 km) and had a lower frequency content $(1-5 \mathrm{~Hz})$, and the onset time of $\mathrm{S}$-waves on seismogram mostly is unclear it arrives almost at the same time with the onset of P-waves (Wassermann 2012). The Seismic zone of VT-A and VT-B is commonly assumed as a manifestation of a small magma chamber, i.e. where the magma is stored temporarily before exploded to the surface (Wassermann 2012).

We manually picked carefully for P- and S-wave was used for arrival times of 3-component waveforms using Seisgram2K (Lomax and Michelini 2009) based on kurtosis and STA/LTA. An example of the P-and S-wave arrival times is presented in Fig. 2. Using the updated arrival times, the earthquake hypocenters were then determined using the Hypoellipse code (Lahr 1979). A 1-D seismic velocity model of AK135 (Kennett et al. 1995) was used in this study. Afterward, the HypoDD program (Waldhauser 2001) was used with arrival times data to implement the double-difference method (Waldhauser and Ellsworth 2000) for relocating the initial hypocenter locations. To ensure the quality of the dataset, only events with a minimum of six phases of arrival time (P- and S-waves) were selected from the initial hypocenter locations. The distance of each event to the seismic station was selected to be no more than 5 degrees to diminish the effect of earth curvature as this study used the Cartesian coordinate system.

The focal mechanism was then inverted for selected events below Mt. Agung. A moment tensor inversion scheme developed by Kuge (1999) was applied in this study. We applied some data processing to our waveform data as follows. First, the instrument responses had to be corrected. Then, windowing was calculated in the length of $20 \mathrm{~s}$ and followed by band-pass filtering from 0.1 to $0.3 \mathrm{~Hz}$. The optimum moment tensor solution was achieved by fitting and synthesizing observational waveforms through the inversion process. The synthetic waveforms calculation used in this study was an extended reflectivity method developed by Kohketsu (1985).

\section{Result and discussion}

In the first step of hypocenter location determination, we successfully located 804 events in the vicinity of Mt. Agung and Mt. Batur (Fig. 3a). To check the reliability of the hypocenter solutions, a Wadati diagram of the arrival time was plotted (Fig. 4). In general, a Vp/Vs ratio of 1.74 was obtained, this value is close to the global average of $\mathrm{Vp} /$ Vs data, i.e., 1.73 (Stein and Wysession 2003), indicating that our $\mathrm{P}$ and $\mathrm{S}$ wave arrival time picking should be close to the actual arrival time.

We have relocated 682 out of 804 events which shows more precise locations (Fig. 3b). The improvement of the travel time residuals before and after double-difference hypocenter relocation is shown in Fig. 5. Furthermore, the problem of fixed depth from the initial locations was also solved (Fig. 6). After relocation, we can see that the events are clustered between Mt. Agung and Mt. Batur with a general strike of NE-SW. The events mainly concentrated at depths of $0-20 \mathrm{~km}$ (below sea level) and showed to move shallow beneath Mt Agung.

Our results show that the seismicity recorded by regional seismic stations have a significantly increased from September 20 to October 19, 2017, with an average of 40 events per day (Fig. 7). This increase of the seismicity is probably related to the migration of magma from deep into shallow magma storage. An interesting feature was observed from October 19 to 21,2017 , in which only four VT events were recorded and located. Syahbana et al. (2019) showed using local 


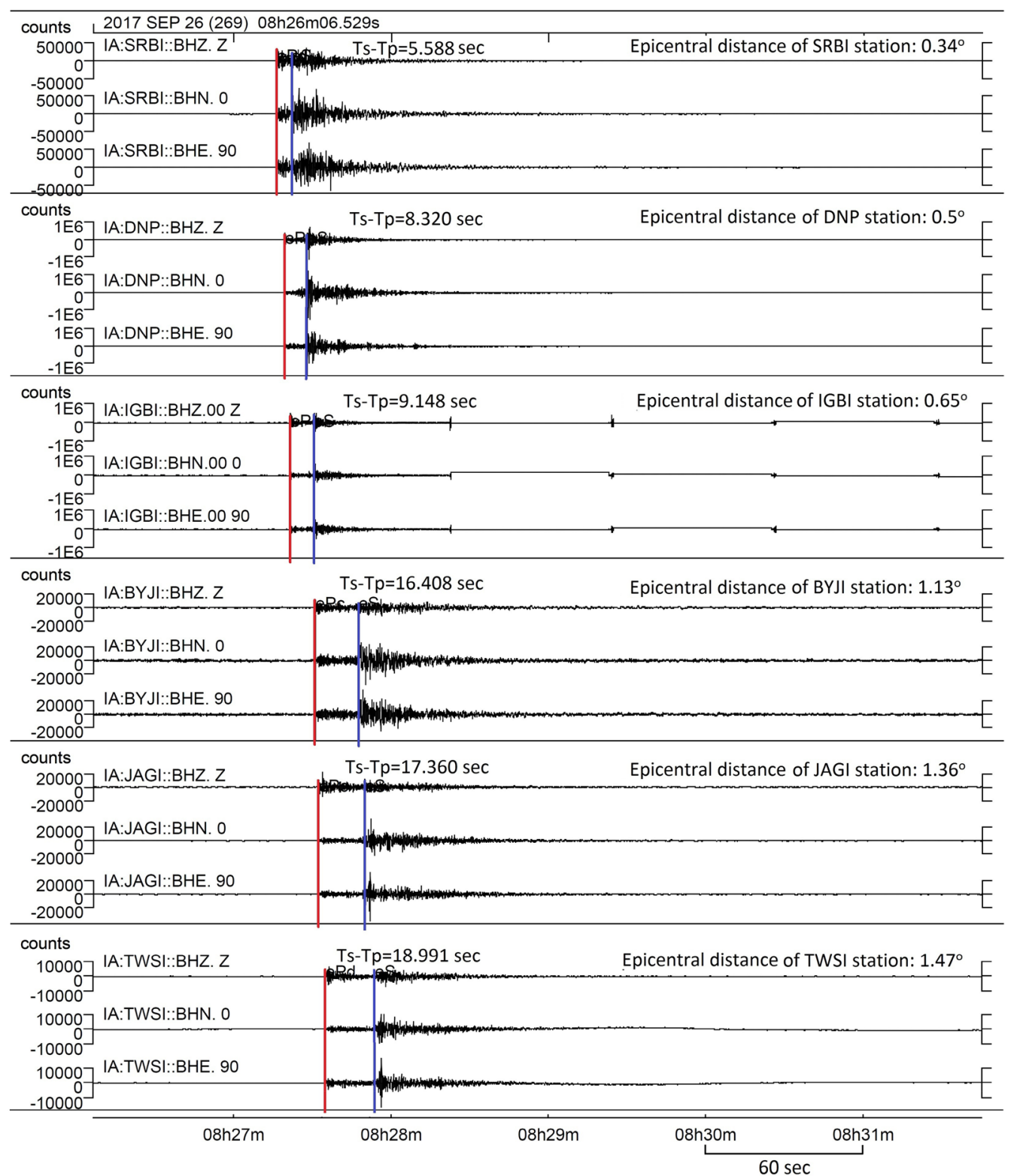

Fig. 2 Example of picked of $P$ and $S$ onset arrival time of the September 26, 2017 event $\left(M_{\perp}\right.$ 4.2) on BMKG seismic network. Red and blue lines indicate pick of P-and S-wave arrival times, respectively

CVGHM stations that VT event rates decreased significantly in late October to early November 2017. This anomaly might indicate that the position of magma had been approaching the shallow magma storage and could potentially trigger an eruption. The relocation events in this study (Fig. 6b line C-D) are in good agreement with the Model 2 of the magma plumbing system beneath Mt. Agung from Syahbana et al. (2019) which concluded uplift as well as the VT events.
To have a better understanding of the magma source mechanism of intrusion, a focal mechanism inversion of selected events was conducted. In total, 11 events were successfully identified for their mechanism (Fig. 8) with the best waveform fitting. Those 11 events have a local magnitude of greater than $M_{L} 3$. Out of those 11 events, 3 clusters were selected according to their location and mechanism. 

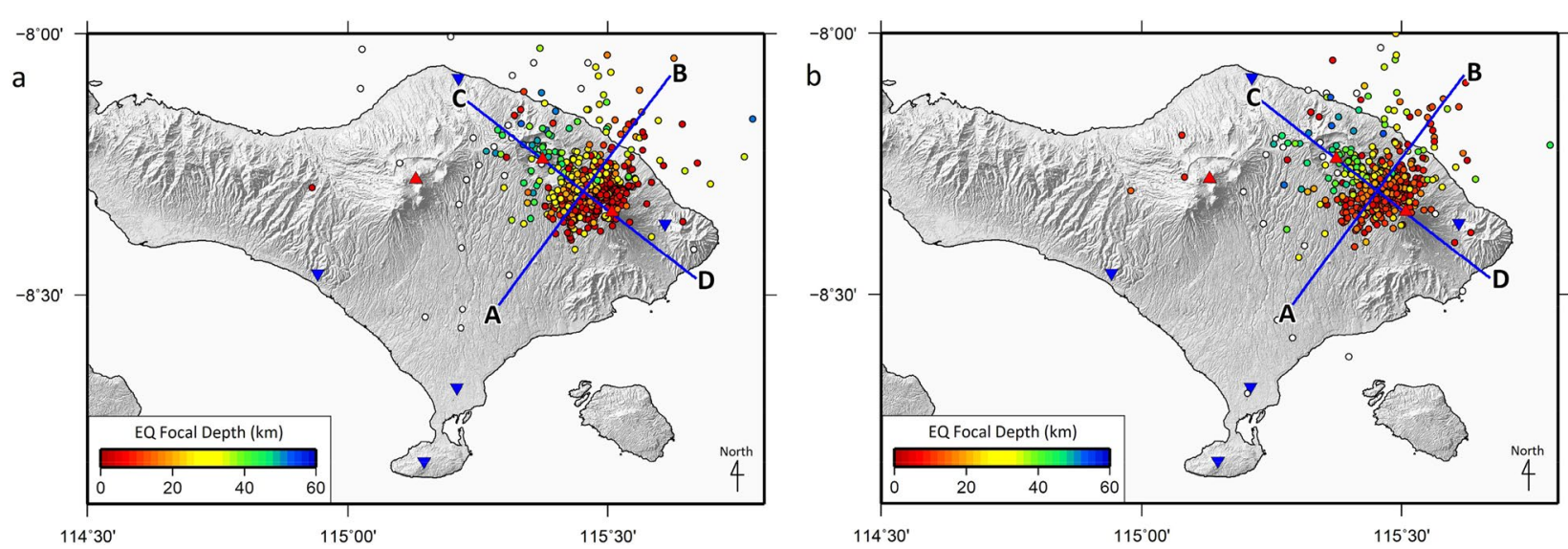

Fig. 3 Map of the earthquakes around Mt. Agung and Mt. Batur. a Distribution of the initial location ( 804 events), and $\mathbf{b}$ after hypocenter relocation in this study (682 events). Colored dots depict the focal depth of hypocenter. Blue inverted triangles show the BMKG seismic stations; red triangles depict volcanoes

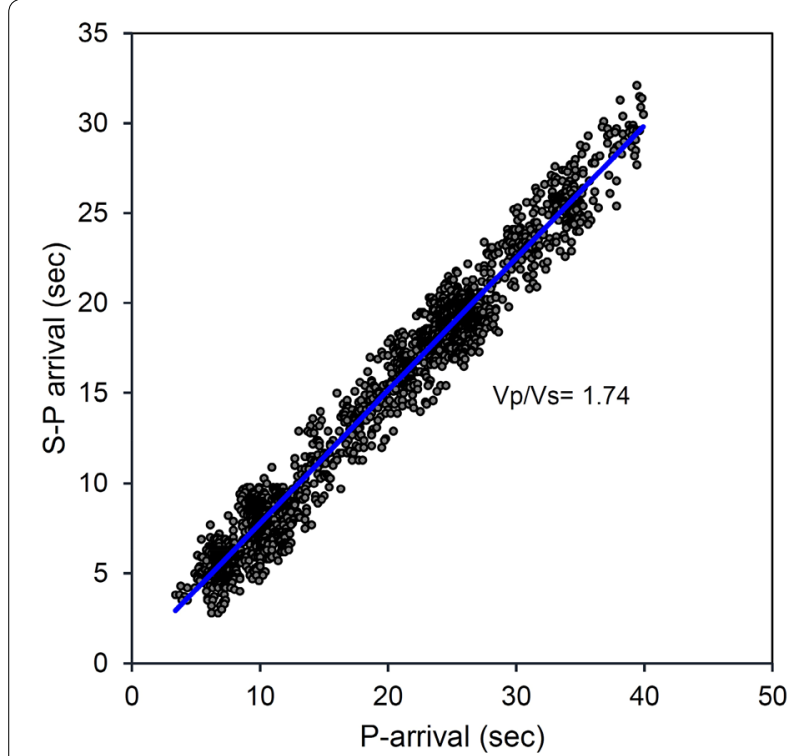

Fig. 4 Wadati diagram for 804 events (initial location) around Mt. Agung and Mt. Batur, the obtained Vp/Ns ratio value is 1.74

We divided the events into three clusters, based on the similarity of focal mechanism types and hypocenter distribution. Cluster I comprises four VT events dominated by strike-slip faulting. The VT distribution of this cluster corresponds to the position of the surface fault observed in the northwestern of Mt. Agung. The source mechanisms of earthquakes in the cluster I indicate a sinistral strike-slip movement, with the strike ranging from $\mathrm{N} 237.0^{\circ} \mathrm{E}$ to $\mathrm{N} 257.9^{\circ} \mathrm{E}$ and dip from $63.47^{\circ}$ to $87.54^{\circ}$. Cluster II consists of six VT events dominated by thrusting. In this cluster, earthquakes occurred at the medial and distal facies. The thrusting fault mechanism probably depicts magma intrusion activity. The intrusion caused lateral forces which could have triggered the development of thrust fault and concentric faulting around the volcano (Bronto 2006). Cluster III shows that normal faulting dominates the eastern area of Mt. Agung. We suspected that this event was positioned at the proximal facies triggered by the combination of gravitational effect and slope topography.

Based on the source mechanism analysis from 11 events, we suggest that the swarm events in the vicinity of Mt. Agung probably were probably triggered by magma intrusion. Magma pushes rock upward, causing inflation and uplift, resulting in tilting at the surface. The largest tilting occurs at the peak and the upper slope, and then decreases downslope. Conversely, when intruded magma eventually cools it reduces its volume and results in deflation, the volcano slope will be inclining inward (Bronto 2006).

Our results from this study give tangible credence to the hypothesis of magma migration underneath Mt. Agung being responsible for the observed seismic swarms observed between September 14 and October 20, 2017, eventually leading up to the November 2017 eruption. A further study of geodetic GPS could be performed to confirm and refine this analysis. 

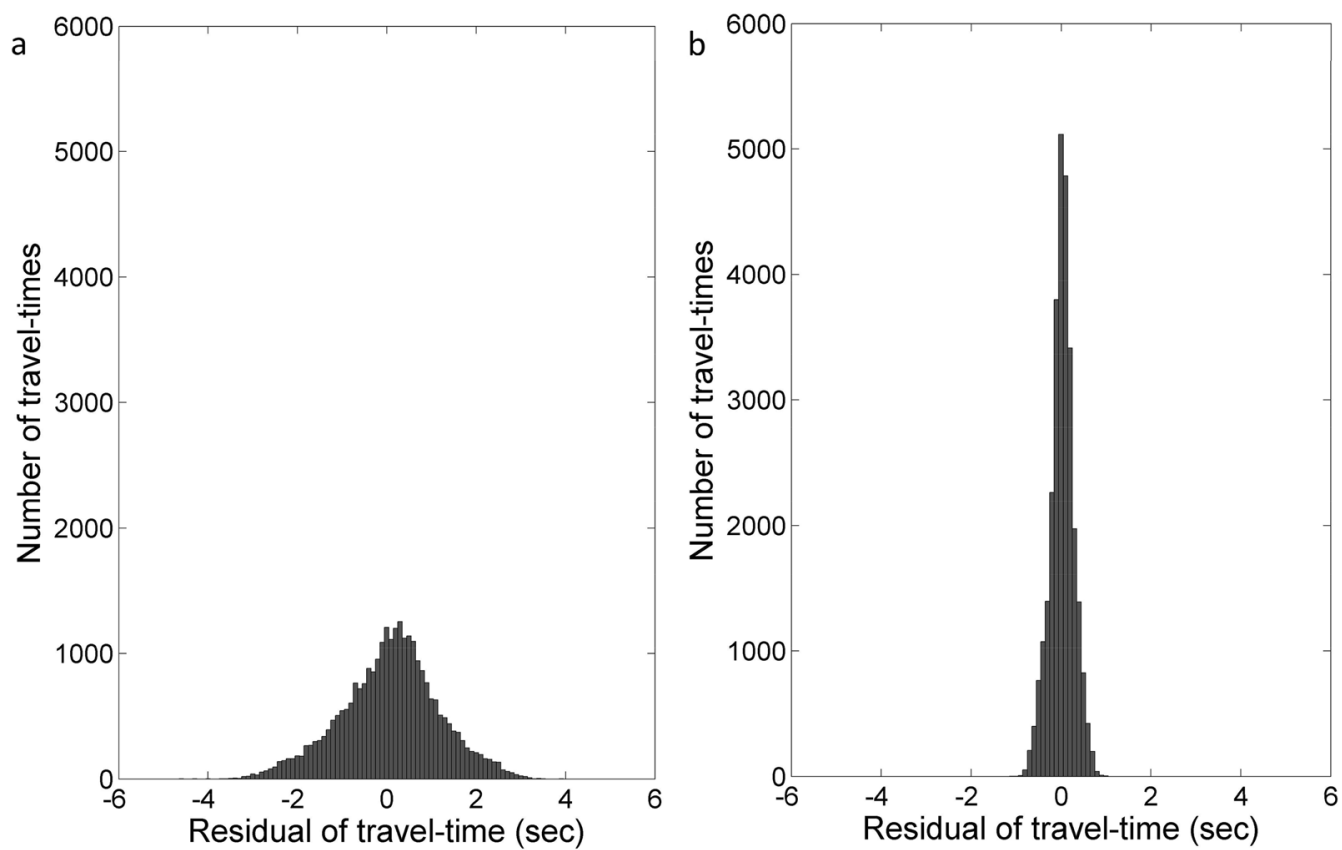

Fig. 5 Histograms of travel-time residuals: a before, and $\mathbf{b}$ after hypocenter relocation for 682 events, respectively

\section{Conclusion}

After we carefully identified and relocated the swarm events and inverted their mechanisms, we could draw the conclusion that magma intrusion was responsible for the observed seismic swarms, especially on VT events. This analysis and interpretation of the volcano's activity were possible due to the high precision hypocenter locations obtained in this study, using the double-difference technique. A significant improvement in the hypocenter location was demonstrated in terms of residual time. In general, the events are located between Mt. Agung and Mt. Batur striking toward NE-SW direction. The occurrence and absence of VT events might be used as an indicator of the presence of magma migration from the deep magma chamber to the shallow magma storage. Focal mechanism solutions further support the impact of magma migration to the seismicity pattern. VT events in Mt. Agung are dominated by thrust faulting at the medial and distal facies, normal fault in proximal facies, and shear fault in the northwestern sector of Mt. Agung. The phenomenon of VT earthquakes at Mt. Agung is significant for volcano observatory operations, to understand the migration of magma toward the crater and as an indicator to determine the status of a volcano in the context of volcano disaster mitigation. Using event locations and their source mechanism, we investigated if the magma intrusion led to the Mt. Agung eruption and its impact on seismicity. More detailed investigations combining data from denser seismic station networks, deformation (GPS), petrology, geochemistry, as well as remote sensing data analysis would lead toward a better understanding of the magmatic plumbing system of Mt. Agung. 

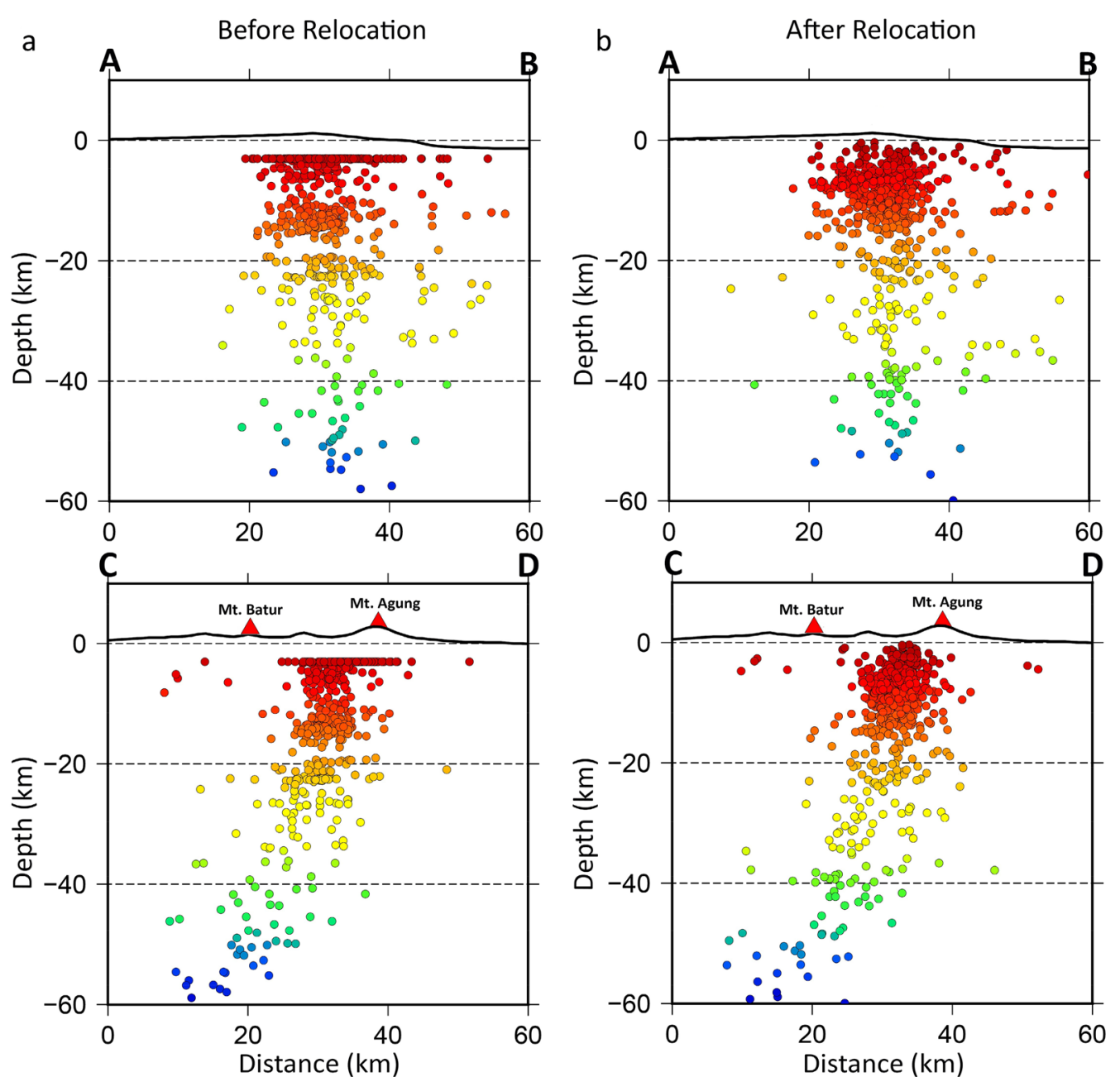

Fig. 6 Vertical cross-section of 682 events (30 km width) for $\mathbf{a}$ before, and $\mathbf{b}$ after relocation in this study. The map of the cross-section line is presented in Fig. 3

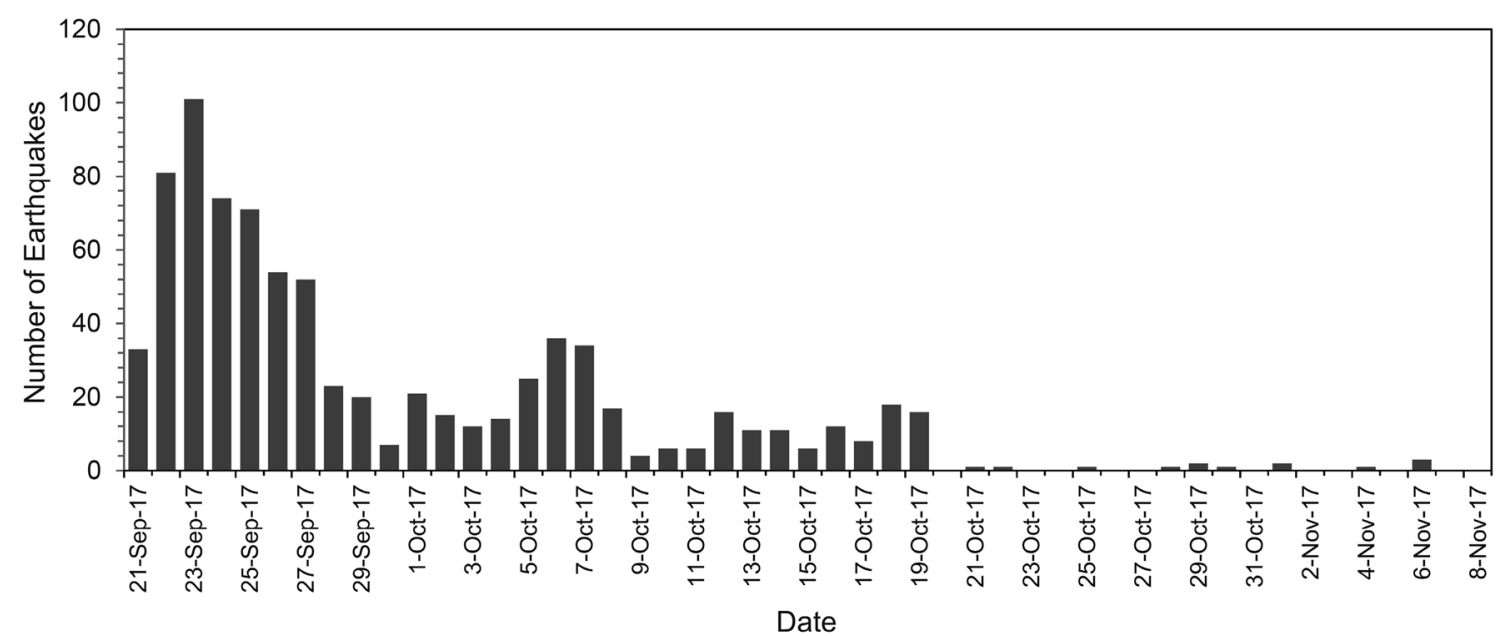

Fig. 7 Histogram of the occurrences of VT events around Mt. Agung from September 19 to November 4, 2017 

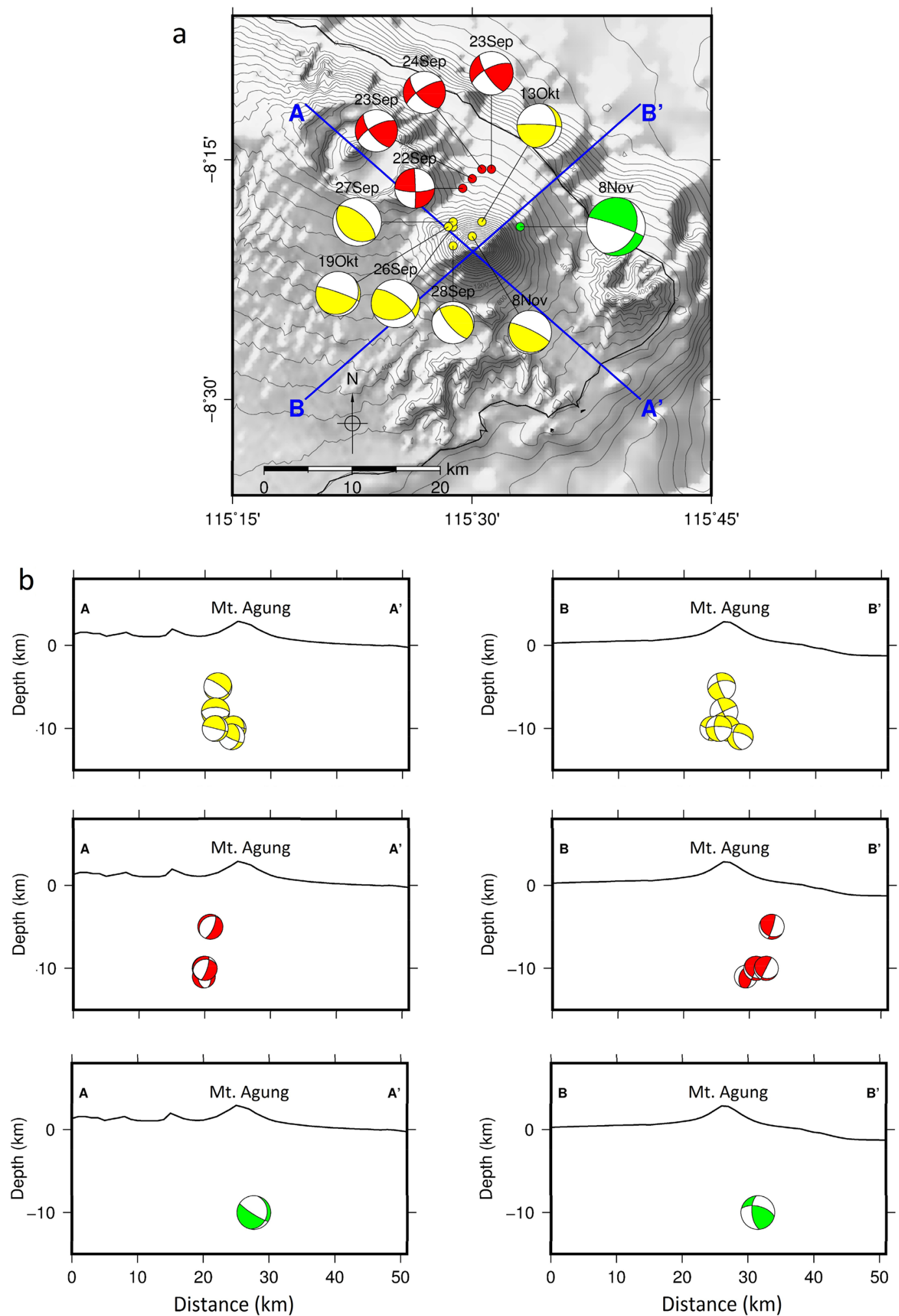

Fig. 8 a Map of focal mechanism of selected VTA earthquakes below Mt. Agung. b Cross-section in northwest-southeast and southwest-northeast directions. The red, yellow and green color indicates the strike-slip, thrust, and normal faulting regime, respectively 


\section{Acknowledgements}

We thank BMKG for the earthquake data used in this study. We thank the guest and lead guest editors for constructive comments. All figures presented were plotted using the Generic Mapping Tools (Wessel and Smith 1998).

\section{Authors' contributions}

MTG, RK, PS, ADN, NTP, D, DPS, ZZ, conceived the study; MTG, RK, PS, ADN, DPS contributed to the writing of the manuscript. All authors contributed to the preparation of the manuscript. All authors read and approved the final manuscript.

\section{Funding}

This study was supported by "Riset ITB 2019" awarded to N. T. P. This study was also partially supported by "Riset Penelitian Dasar Unggulan Perguruan Tinggi (PDUPT) BP-PTNBH Kemristek/BRIN 2019-2020", "Riset Tesis Magister BP-PTNBH Kemristek/BRIN 2020", and "Riset ITB 2019-2020" awarded to A.D.N., and was partially supported by Center for Earthquake Science and Technology, Research Center for Disaster Mitigation, Institut Teknologi Bandung (CEST, PPMB, ITB).

\section{Availability of data and materials}

Earthquake data are available from the authors upon request.

\section{Competing interests}

We declare that we have no significant competing financial, professional or personal interests that might have influenced the performance or presentation of the work described in this manuscript.

\section{Author details}

${ }^{1}$ Agency for Meteorology, Climatology, and Geophysics (BMKG), Jakarta 10610, Indonesia. ${ }^{2}$ Center for Earthquake Science and Technology (CEST), Research Center for Disaster Mitigation, Institut Teknologi Bandung, Bandung 40132, Indonesia. ${ }^{3}$ Global Geophysics Research Group, Faculty of Mining and Petroleum Engineering, Institut Teknologi Bandung, Bandung 40132, Indonesia.

Received: 8 March 2019 Accepted: 23 September 2020

Published online: 06 October 2020

\section{References}

Albino F, Biggs J, Syahbana DK (2019) Dyke intrusion between neighbouring arc volcanoes responsible for 2017 pre-eruptive seismic swarm at Agung. Nat Commun 10:748. https://doi.org/10.1038/s41467-019-08564-9

Bronto S (2006) Fasies gunung api dan aplikasinya. Indones J Geosci. https:// doi.org/10.17014/ijog.vol1 no2.20061

I guchi M, Ishiara K, Surono, Hendrasto M (2011) Learn from 2010 eruptions at Merapi and Sinabung volcanoes in Indonesia. Annuals of Disaster Prevention Research Institute. Kyoto University (54 B)

Kennett BLN, Engdahl ER, Buland R (1995) Constraints on seismic velocities in the Earth from traveltimes. Geophys J Int 122:108-124. https://doi. org/10.1111/j.1365-246X.1995.tb03540.x

Kohketsu K (1985) The extended reflectivity method for synthetic near-field seismograms. Journal of Physics of the Earth 33:121-131. https://doi. org/10.4294/jpe1952.33.121

Kuge K (1999) Automated determination of earthquake source parameters using broadband strong-motion waveformdata. EOS Trans Am Geophys Union. https://doi.org/10.1785/0120020076

Kusumadinata K (1964) The eruption of the Agung volcano in Bali in 1963. Bull Geol Surv Indones 1:12-15

Lahr JC (1979) HYPOELLIPSE: a computer program for determining local earthquake hypocentral parameters, magnitude, and first motion pattern. USGS Publ Wareh. https://doi.org/10.3133/ofr79431

Lomax A, Michelini A (2009) Mwpd: a duration-amplitude procedure for rapid determination of earthquake magnitude and tsunamigenic potential from P waveforms. Geophys J Int 176:200-214. https://doi.org/10.1111/ j.1365-246X.2008.03974x

McCausland W, Gunawan H, White RA, Indrastuti N, Patria C, Suparman Y, Putra A, Triastuty H, Hendrasto M (2017) Using a process-based model of pre-eruptive seismic patterns to forecast evolving eruptive styles at Sinabung Volcano, Indonesia. J Volcanol Geotherm Res. https://doi. org/10.1016/j.jvolgeores.2017.04.004

McGuire WJ (1992) Monitoring active volcanoes: procedures and prospects. Proc the Geol Assoc 103(4):303-320. https://doi.org/10.1016/s0016 $-7878(08) 80128-9$

McNutt SR (2002) Volcano seismology and monitoring for eruptions. Int Geophys. 81:383

Nugraha AD, Indrastuti N, Kusnandar R, Gunawan H, McCausland W, Aulia AN, Harlianti U (2017a) Joint 3-D tomographic imaging of Vp, Vs and Vp/Vs and hypocenter relocation at Sinabung volcano, Indonesia from November to December 2013. J Volcanol Geoth Res. https://doi.org/10.1016/j. jvolgeores.2017.09.018

Nugraha AD, Shiddiqi HA, Widiyantoro S, Puspito NT, Triyoso W, Wiyono S, Daryono Wandono, Rosalia S (2017b) Hypocenter Relocation of Earthquake Swarm in West Halmahera, North Molucca Region, Indonesia by using Double-Difference Method and 3D Seismic Velocity Structure. IOP Conf Ser Earth Environ Sci 62:012053. https://doi.org/10.1088/17551315/62/1/012053

Nugraha AD, Supendi P, Widiyantoro S, Daryono Wiyono S (2018a) Hypocenter relocation of earthquake swarm around Jailolo volcano, North Molucca, Indonesia using the BMKG network data: time periods of September 27-October 10, 2017. AIP Conf Proc 1987:020093. https://doi. org/10.1063/1.5047378

Nugraha AD, Supendi P, Widiyantoro S, Daryono Wiyono S (2018b) Earthquake swarm analysis around Bekancan area, North Sumatra, Indonesia using the BMKG network data: time periods of February 29, 2015 to July 10, 2017. AIP Conf Proc 1987:020092. https://doi.org/10.1063/1.5047377

Santoso D, Wahyudi EJ, Kadir WGA et al (2018) Gravity structure around Mt. Pandan, Madiun, East Java, Indonesia and its relationship to 2016 seismic activity. Open Geosci 10:882-888. https://doi.org/10.1515/geo-2018-0069

Self S, Rampino MR (2012) The 1963-1964 eruption of Agung volcano (Bali, Indonesia). Bull Volcanol 74(6):1521-1536. https://doi.org/10.1007/s0044 5-012-0615-z

Stein S, Wysession M (2003) An introduction to seismology, earthquakes, and earth structure. Blackwell Pub, Malden

Supendi P, Nugraha AD, Puspito NT, Widiyantoro S, Daryono D (2018) Identification of active faults in West Java, Indonesia, based on earthquake hypocenter determination, relocation, and focal mechanism analysis. Geosci Lett. https://doi.org/10.1186/s40562-018-0130-y

Syahbana DK, Kasbani K, Suantika G, Prambada O, Andreas AS, Saing UB, Kunrat SL, Andreastuti S, Martanto M, Kriswati E, Suparman Y, Humaida H, Ogburn S, Kelly PJ, Wellik P, Wright HMN, Pesicek JD, Wessels R, Kern C, Lisowski M, Diefenbach A, Poland M, Beauducel F, Pallister J, Vaughan RG, Lowenstern JB (2019) he 2017-19 activity at Mount Agung in Bali (Indonesia): intense unrest, monitoring, crisis response, evacuation, and eruption. Sci Rep. https://doi.org/10.1038/s41598-019-45295-9

Waldhauser $F$ (2001) hypoDD-A program to compute double-difference hypocenter locations. USGS Open File Rep 2001:113

Waldhauser F, Ellsworth WL (2000) A Double-Difference Earthquake Location Algorithm: method and Application to the Northern Hayward Fault, California. Bull Seismol Soc Am 90:1353-1368. https://doi.org/10.1785/0120000006

Wassermann J (2012) Volcano Seismology. New Manual of Seismological Observatory Practice 2 (NMSOP2). https://doi.org/10.2312/gfz.nmsop-2_ch13

Wessel P, Smith WHF (1998) New, improved version of generic mapping tools released. Eos Trans Am Geophys Union 79:579. https://doi. org/10.1029/98EO00426

Widiyantoro S, Ramdhan M, Métaxian J-P, Cummins PR, Martel C, Erdmann S, Nugraha AD, Santoso AB, Laurin A, Fahmi AA (2018) Seismic imaging and petrology explain highly explosive eruptions of Merapi Volcano, Indonesia. Sci Rep 8:13656. https://doi.org/10.1038/s41598-018-31293-w

Zen MT, Hadikusumo D (1964) Preliminary report on the 1963 eruption of Mt.Agung in Bali (Indonesia). Bull Volcanologique 27:269-299. https://doi. org/10.1007/BF02597526

\section{Publisher's Note}

Springer Nature remains neutral with regard to jurisdictional claims in published maps and institutional affiliations. 